\title{
Developing Teaching Material in Natural Science Subject Using Inductive Thinking Models to Improve Critical Thinking of $4^{\text {th }}$ Grade Students
}

\author{
Sri Kosmita ${ }^{1}$, Sukarno ${ }^{2}$, Salamah ${ }^{3}$ \\ 1,2,3 Program Studi Pendidikan Guru Madrasah Ibtidaiyah, Institut Agama Islam Negeri Bengkulu, \\ Indonesia \\ Jl. Raden Fatah Kec. Selebar Kota Bengkulu, Bengkulu 38211 \\ Coressponding Author E-mail: \\ 2sukarno@iainbengkulu.ac.id \\ 33salamah@iainbengkulu.ac.id
}

Received: January $10^{\text {th }}, 2020$

Accepted: January $28^{\text {th }}, 2020$

Online Published: January 31 $1^{\text {st }}, 2020$

\begin{abstract}
Abstrak
There are lack of science student worksheet based on inductive thinking in the education system are. So the purpose of this study is to create appropriate and good student worksheet teaching material using inductive thinking model in science learning, and to test whether there are differences in students' critical thinking by using science teaching materials based on inductive thinking model compared to conventional teaching materials in SDN 66 Kota Bengkulu. This type of research is R\&D (Research and Developmet), which was developed using the Borg and Gall model proposed by Sugiyono. The instruments in this study were questionnaire and essay test. The data analysis technique used is the "t" test. The results of the study that teaching materials are appropriate according to the material experts, teachers and the product is also good according to students. Teaching material about force in science using LKS based on inductive thinking model can improve the critical thinking of SDN 66 students in Bengkulu City. This is also evidenced by the results of the "t" test obtained at sig $0.00<0.05$. Thus $\mathrm{Ha}$ is accepted and $\mathrm{H} 0$ is rejected, which means that there is a significant difference between students who use science teaching materials based on inductive thinking models with conventional teaching materials at SDN 66 Bengkulu City.
\end{abstract}

Kata kunci: Students Worksheet; Inductive thinking models; Critical thinking,

How to cite this article :

Kosmita, S., Sukarno, S., \& Salamah, S. (2020). Developing Teaching Material in Natural Science Subject Using Inductive Thinking Models to Improve Critical Thinking of 4th Grade Students. IJIS Edu : Indonesian Journal of Integrated Science Education, 2(1), 63-74. doi:http://dx.doi.org/10.29300/ijisedu.v2i1.2733 


\section{INTRODUCTION}

The quality of education in Indonesia is considered by many to be still low. The low quality of Indonesian education is even more noteworthy with data from Indonesian Ministry of Youth and Sport which states that as many as $37.06 \%$ of Indonesian youth only graduate from Elementary School (Raharjo, 2012). There are many factors that influence the graduates such as clear teaching goals, adequate teaching materials, appropriate teaching methodologies, and good ways of assessment. In the learning methodology there are two aspects that are most prominent, they are teaching methods and teaching media. As for teaching aids, teaching medium is one of the learning environments designed by the teacher (Alannasir, 2016; Carlson, 1982; Khosi'in, 2019; Ondeng, 2007; Styawati \& Rizal, 2017). One of the characteristics of good quality learning implementation is the use of good tools. Provision of skills gained from educational institutions is not sufficient to be used independently, because what is learned in educational institutions is often only fixated on theory, so students are less innovative and creative (Bibigul, Orynkul, Lyudmila, \& Aelita, 2015; Prasetyaningtyas, 2019). Therefore, the key to increasing Indonesia's competitiveness is by improving the quality of education and making new and creative breakthrough teachers in the education sector.

Innovative teachers are those who are able to create something new in the form of resources that are up to date. Teachers are more open to new ideas, skilled communication and are willing to take risks, guiding students with sincerity and affection and showing respect towards the opinions of others. Innovative teachers can influence students in teaching and learning. Teacher must be able to create a teaching and learning process that helps students to learn actively and dynamically in meeting their needs and create a pleasant learning atmosphere.

From the survey conducted by researchers through interviews towards teachers and students of Public Elementery School 66 Bengkulu City, along with the class observation, it turned out that there were still many teachers who did not understand their duties as teachers to be innovative and creative. Teachers used printed books more often than using Student Worksheets, teachers had difficulty in creating student worksheet based on innovative learning models and there were still many teachers not paying enough attention to students who did not understand the learning material, teachers did not take action against students who were not focused in the teaching and learning process. If the teacher did the learning process in such a way, then the teaching and learning process did not reflect the learning objectives. Supposedly, in the teaching and learning process teachers had to understand their assignments guideline and direct their students to be active in learning by motivating and approaching them in an effort to help students in solving material that was difficult, especially in science learning. Learning science was not only a collection of knowledge about objects or living things, but students also were given the opportunity to practice the science process skills, because they were expected to be able to think and have a scientific nature (Freestone \& O’Toole, 2016; Kristyowati \& Purwanto, 2019). Critical thinking is very necessary to develop attitudes and perceptions that support the creation of positive classroom conditions, acquire and integrate knowledge, broaden knowledge horizons, and actualize the meaningfulness of knowledge. Critical thinking is needed to face the modern world where all information is provided instantly. It also helps students improve understanding of the material being studied by critically evaluating arguments in textbooks, journals, discussion partners, including teacher arguments in learning activities. So students can use the potential of the mind optimally, so that they become careful readers and creative writers (Afat \& Kadığlu Ateş, 2019; Amin, 2017; Buckingham \& Scanlon, 2001; Riswanto \& Dewi, 2017; Rudyanto, 2016).

Considering the problems found by the researchers, the teacher is highly demanded to be more creative. Teacher must be able to develop a teaching material in the form of worksheets that can attract students' attention, generate student motivation, and improve students' understanding of concepts in science teaching and learning activities. Student worksheet is one of the student learning tools that contains various activities that will be actively carried out by students. These activities can be in the form of observations, experiments, and asking questions

Inductive models can help students gather information and test it carefully, processing information into these concepts. If this strategy used gradually, it can also improve students' ability to form concepts efficiently and increase the range of perspectives from which they view 
information (Aditama, 2015; M. Prince \& Felder, 2007; M. J. Prince \& Felder, 2006).

Student Worksheets are teaching materials that have been packaged in such a way that students can learn teaching materials independently (Rudyanto, 2016; Rusnilawati, 2016; Sulistyowati \& Sugiman, 2014). Student worksheet does not only contain the assignment sheet but also a series of summary material to understand the questions given. Student worksheets contain a set of basic activities that must be carried out by students to maximize understanding in an effort to form basic abilities according to indicators of achievement of learning outcomes that must be pursued (Bathgate \& Schunn, 2017; Selviani, 2019). Based on the understanding of Student Worksheets, then there is a it's function itself. (Prastowo, 2013) formulates the function of student worksheet as 1) As a teaching material that can minimize the role of educators, but more activates students; 2) As teaching materials that make it easier for students to understand the material provided; 3) As a concise and rich teaching material for the task of practicing; and 4) Facilitating the implementation of teaching to students.

\section{RESEARCH METHOD}

This article used Research and Development as research method. The procedure used referred to the steps developed by Borg and Gall. According to Borg \& Gall, (1983) in Emzir, the steps in research and development are as the table 1.

Table 1. Research and development steps

\begin{tabular}{ll}
\hline $\begin{array}{l}\text { Main procedures } \\
\text { in Borg dan Gall }\end{array}$ & \multicolumn{1}{c}{$\begin{array}{c}\text { Steps in Borg dan } \\
\text { Gall }\end{array}$} \\
\hline $\begin{array}{l}\text { Research and } \\
\text { information collecting }\end{array}$ & $\begin{array}{l}\text { 1. Research and } \\
\text { information gathering }\end{array}$ \\
\hline Planning & 2. Planning \\
\hline $\begin{array}{ll}\text { Develop preliminary } \\
\text { form of product }\end{array}$ & $\begin{array}{l}\text { 3. Development of } \\
\text { initial forms of products }\end{array}$ \\
field testing and & $\begin{array}{l}\text { 4. Initial field test } \\
\text { product revision }\end{array}$ \\
& $\begin{array}{l}\text { 5. Product revision } \\
\text { 6. Main field test }\end{array}$ \\
& 7. Revised operational \\
& $\begin{array}{l}\text { products } \\
\text { 8. Operational field } \\
\text { testing }\end{array}$ \\
\hline
\end{tabular}

\begin{tabular}{ll}
\hline Final product revision & $\begin{array}{l}9 . \text { Revision of the final } \\
\text { product }\end{array}$ \\
\hline
\end{tabular}

The type of study used here was research and development in the form of worksheet. Then, the product was tested through experiments. The subjects in this study were $4^{\text {th }}$ grade students who were divided into two groups, they were $4^{\text {th }}$ grade $A$ as an experimental group and $4^{\text {th }}$ grade $\mathrm{B}$ as a control group and the design was Pretest Only Control Design and Pretest Group Design

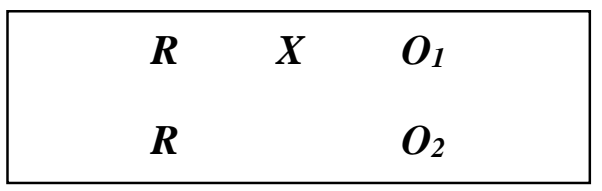

Figure 1. Pretest-Only Control Design

In this design there were two groups, each randomly chosen $(\mathrm{R})$. The first group was given treatment $(\mathrm{X})$ and the other group was not. The treated group was called the experimental group and the untreated group was called the control group. The effect of the treatment was (O1: O2). In real research, the effect of treatment was analyzed by different tests, using statistical t-tests for example. If there was a significant difference between the experimental group and the group control, then the treatment given had a significant effect (Sugiyono, 2007)

Data Collection Techniques used in this study were questionnaires to obtain information about students' responses to the learning used. The filling out of the learning response questionnaires was done at the end of the whole lesson. The questionnaires developed in this study used a Likert scale with four response categories: strongly agree $(\mathrm{SA})$, agree $(\mathrm{A})$, disagree $(\mathrm{DA})$, strongly disagree (SDA), Neutral $(\mathrm{N})$. choices were not given to avoid safe answers, thus required students to state their alignment with the statement given. A description test or essay test was a form of question that demanded students' answers in the form of a description using their own language. In the form of a test description students were required to think about using what was known about the questions that must be answered (SAREGAR et al., 2019; Sutarto, Indrawati, Prihatin, \& Dwi, 2018).

Data analysis techniques used two techniques, they were descriptive statistical analysis and inferential statistics. Descriptive statistical analysis was used to describe the response to the product produced such as 
Student Worksheet, while inferential statistics were used to test hypotheses with the "t" test.

\section{RESULTS AND DISCUSSION}

\section{Results}

Presentation of the results of research in this study was to determine the competency standards, basic competencies, and indicators of success, develop evaluation items, develop and select subject material for the development of syllabus, lesson plans, worksheets for science subjects style materials, inductive thinking learning models, and research instruments about critical thinking essays. The subject matter developed aimed to provide knowledge to students about the science material. Furthermore, the assessment of media and electrical circuit material was obtained from the results of the validation by the media experts and the validation of the material experts. The student's assessment of the feasibility of this worksheet was obtained using student questionnaires.

The product that had been through validation by the experts was then tested on respondents. The respondents of this product were 64 students of Public Elementery School 66 Bengkulu City. The test was conducted in two different classes, they were $4^{\text {th }} \mathrm{A}$ Grade and $4^{\text {th }} \mathrm{B}$ Grade, which consisted of 32 students each. The product trial step was carried out by displaying product in the form of worksheets in front of the class, then distributing questionnaires to students.

Presentation of the results from the development of the science worksheet subject obtained from the results of the validation of the media expert and the validation of the material expert, as well as the students' perceptions, were presented in table 2:

Table 2. Total Respondent Scores

\begin{tabular}{|c|c|c|c|c|c|c|c|c|}
\hline & \multicolumn{4}{|c|}{ Grade 4 A } & \multicolumn{4}{|c|}{ Grade 4 B } \\
\hline No & $\begin{array}{l}\text { Respondent } \\
\text { scores }\end{array}$ & $\begin{array}{l}\text { Number } \\
\text { (F) }\end{array}$ & $\begin{array}{l}\text { Mean } \\
\text { (X1) }\end{array}$ & $\mathbf{F X}_{1}$ & $\begin{array}{l}\text { Respondent } \\
\text { scores }\end{array}$ & $\begin{array}{l}\text { Number } \\
\text { (F) }\end{array}$ & $\begin{array}{l}\text { Mean } \\
\text { (X12) }\end{array}$ & $\mathbf{F X}_{2}$ \\
\hline 1 & 32 & 1 & 2.67 & 2.67 & 31 & 3 & 2.58 & 7.74 \\
\hline 2 & 36 & 5 & 3.00 & 15.00 & 35 & 7 & 2.92 & 20.44 \\
\hline 3 & 40 & 8 & 3.33 & 26.64 & 39 & 6 & 3.25 & 19.5 \\
\hline 4 & 43 & 8 & 3.58 & 28.64 & 41 & 4 & 3.42 & 13.68 \\
\hline 5 & 45 & 7 & 3.75 & 26.25 & 43 & 7 & 3.58 & 25.06 \\
\hline 6 & 48 & 3 & 4.00 & 12.00 & 46 & 5 & 3.83 & 19.15 \\
\hline & & & & 111.20 & & & & 105.57 \\
\hline & Ave & ge scores & & 3.475 & & & & 3.30 \\
\hline
\end{tabular}

From the results of small group tests conducted towards the students, the results were displayed in table 3 :

Table 3. Frequency distribution of small group test response values

The results of improvements (after revision from expert judgement) that researchers made is visually can be seen in the figure 2 .

\begin{tabular}{cccc}
\hline No & Scores & Number & Description \\
\hline 1 & 85 & 1 & Very good \\
\hline 2 & 80 & 1 & Very good \\
\hline 3 & 75 & 1 & Good \\
\hline 4 & 70 & 1 & Good \\
\hline 5 & 65 & 1 & Enough \\
\hline
\end{tabular}




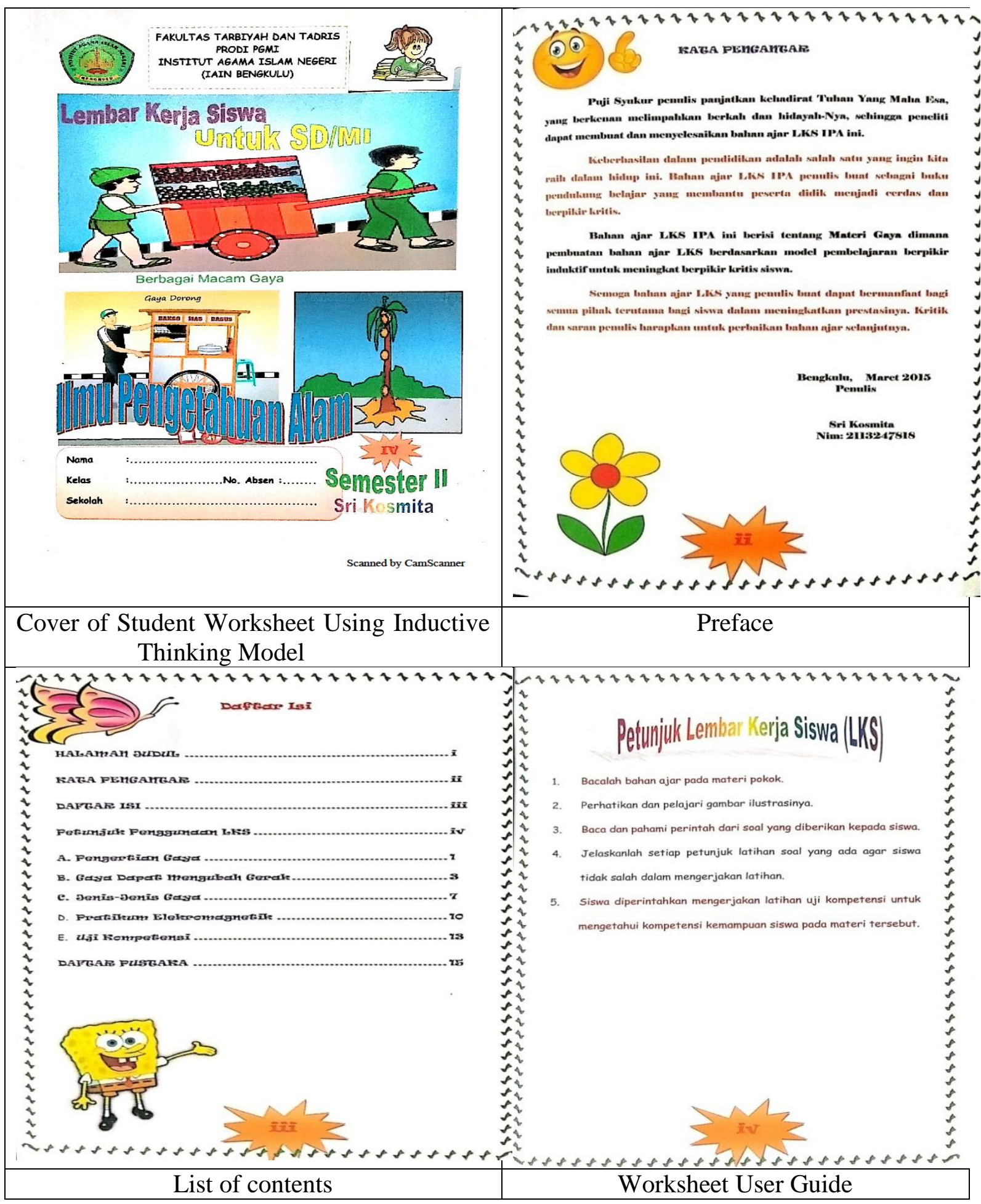

Figure 2. Student Worksheet after the revision

From the results of a large group trial, the frequency distribution of the score in experimental class was as seen as table 4 
Table 4. Frequency distribution of scores in large group test

\begin{tabular}{cccc}
\hline No & Scores & Number & Description \\
\hline 1 & 90 & 3 & Very good \\
\hline 2 & 85 & 7 & Very good \\
\hline 3 & 80 & 8 & Good \\
\hline 4 & 75 & 8 & Good \\
\hline 5 & 70 & 5 & Good \\
\hline 6 & 65 & 1 & Enough \\
\hline
\end{tabular}

d. Test Result Data

1) Experiment Class Test Results Data

Based on the results of essay tests given to the experimental group, the total score was 2595 from 32 students with an average value of 81.09.

2) Control Class Test Result Data

Based on the results of the essay test given to the control group, the total score was 1605 from 32 students with an average value of 50.15 .

2. Normality and Homogeneity Test

a. Normality test

1) Test the normality of the experimental class

Table 5. Tests of Normality

\begin{tabular}{|c|c|c|c|c|c|c|}
\hline \multirow{2}{*}{} & \multicolumn{2}{|c|}{ Kolmogorov-Smirnova } & \multicolumn{3}{|c|}{ Shapiro-Wilk } \\
\cline { 2 - 6 } & Statistic & $\mathrm{df}$ & Sig. & $\begin{array}{c}\text { Statisti } \\
\mathrm{c}\end{array}$ & $\mathrm{df}$ & Sig. \\
\hline $\begin{array}{c}\text { Resu } \\
\mathrm{lt}\end{array}$ &, 131 & 32 &, 173 &, 943 & 32 &, 093 \\
\hline
\end{tabular}

a. Lilliefors Significance Correction

1). Test the normality of the control class

Table 6. Tests of Normality

Tabel 4.9. Tests of Normality

\begin{tabular}{|r|r|r|r|r|r|r|}
\hline \multirow{2}{*}{} & \multicolumn{3}{|c|}{ Kolmogorov-Smirnov } & \multicolumn{3}{|c|}{ Shapiro-Wilk } \\
\cline { 2 - 7 } & Statistic & df & Sig. & Statistic & df & Sig. \\
\hline Result &, 145 & 32 &, 083 &, 952 & 32 &, 16 \\
& & & & & & 4 \\
\hline
\end{tabular}

a. Lilliefors Significance Correction

The tabale 5 and 6 above show that each variable is greater than 0.05 . (0.093>0.05 for the experimental class and $0.083>0.05$ for the control class). It means that the two data were normally distributed.

b. Homogeneity Test

Table 7. Test of Homogeneity of Variance

\begin{tabular}{|ll|l|l|l|l|}
\hline & $\begin{array}{l}\text { Levene } \\
\text { Statistic }\end{array}$ & df1 & df2 & Sig. \\
\hline Test & Based on Mean & 1,871 & 1 & 62 &, 176 \\
result & Based on Median & 1,429 & 1 & 62 &, 237 \\
& $\begin{array}{l}\text { Based on Median } \\
\text { and with }\end{array}$ & 1,429 & 1 & 56,713 &, 237 \\
& adjusted df & & & \\
& $\begin{array}{l}\text { Based on } \\
\text { trimmed mean }\end{array}$ & 1,936 & 1 & 62 &, 169 \\
\hline
\end{tabular}

The table 7 shows that the significance value of each variable is greater than 0.05. Likewise, the significance value of the homogeneity test results of $0.169>0.05$, which means that both data are homogeneous. 


\begin{tabular}{|c|c|c|c|c|c|c|c|c|c|c|}
\hline & \multicolumn{2}{|c|}{$\begin{array}{c}\text { Levene's Test for } \\
\text { Equality of } \\
\text { Variances }\end{array}$} & \multicolumn{7}{|c|}{ t-test for Equality of Means } \\
\hline & & \multirow[b]{2}{*}{$\mathrm{F}$} & \multirow[b]{2}{*}{ Sig. } & \multirow[b]{2}{*}{$\mathrm{t}$} & \multirow[b]{2}{*}{ df } & \multirow{2}{*}{$\begin{array}{l}\text { Sig. (2- } \\
\text { tailed) }\end{array}$} & \multirow{2}{*}{$\begin{array}{c}\text { Mean } \\
\text { Difference }\end{array}$} & \multirow{2}{*}{$\begin{array}{l}\text { Std. Error } \\
\text { Difference }\end{array}$} & \multicolumn{2}{|c|}{$\begin{array}{l}\text { 95\% Confidence } \\
\text { Interval of the } \\
\text { Difference }\end{array}$} \\
\hline & & & & & & & & & Lower & Upper \\
\hline $\begin{array}{l}\text { berpikir } \\
\text { kritis }\end{array}$ & $\begin{array}{l}\text { Equal } \\
\text { variances } \\
\text { assumed } \\
\text { Equal } \\
\text { variances } \\
\text { not } \\
\text { assumed }\end{array}$ & 4.131 & .046 & 11.319 & 49.963 & .000 & 30.938 & 2.733 & 25.474 & 36.401 \\
\hline
\end{tabular}

The results of the output with the " $t$ " test analysis shows that the sig value $<0.05(0.00$ $<0.05)$. Then $\mathrm{Ha}$ is accepted and $\mathrm{H}_{0}$ is rejected so it can be concluded that there were differences in students' critical thinking between students who used teaching materials Science student worksheet subjects based on inductive thinking learning models with students who used conventional learning teaching materials in Public Elementery School 66 Bengkulu City.

\section{Discussion}

After the total score of the answers from the respondents was collected, the next step is making the decision based on the classification table of respondents' perceptions towards student worksheet teaching material product. It is presented in the table 9:

Table 9. Classification of Student Perceptions of LKS teaching material products using inductive thinking models

\begin{tabular}{llll}
\hline No & \multicolumn{2}{l}{ Score mean } & Description \\
\hline 1 & $>$ & $3.25-4$ & Very good \\
2 & $>$ & $2,5-3.25$ & Good \\
3 & $>$ & $1.75-2.5$ & Bad \\
4 & $>$ & $1.00-1.75$ & Very bad \\
\hline
\end{tabular}

Table 2. shows that the total score of the answers obtained from students' assessments of student worksheet teaching material product model in $4^{\text {th }}$ A grade was 111.20, with the average answer for all students was 3,475. If the results are consulted with table 9 which shows the classification of perceptions based on the number of answers, then the criteria of the outcomes is "Very Good", because it is included in the class interval $>3.25-4$

The same method was done in $4^{\text {th }} \mathrm{B}$ grade, for the total number of answers in $4^{\text {th }} \mathrm{B}$ grade was 105.57, while the average was 3.30. If the results are consulted with a classification table based on the total score of the answers, then it is categorically "Very Good", because it is included in the interval class $>3.25-4$

Table 2 shows that the total score of the answers obtained from students' perceptions towards student worksheet teaching material product using the inductive thinking model in $4^{\text {th }}$ A grade is 111.20 , with an average answer of all 3.475 students. If the results are consulted with table 9 namely the classification of attitudes based on the number of answers, then it is categorically "Very Good", because it is included in the class interval> $3.25-4$

The same method is done in $4^{\text {th }} \mathrm{B}$ grade, for the total number of answers in $4^{\text {th }} \mathrm{B}$ grade is 105.57, while the average is 3.30. If the results are consulted with a classification table based on the total score of the answers, then it includes "Very Good", because it is included in the interval class $>3.25-4$

From the results of the table 2, the average respondent's answers in the form of a diagram is in figure 3: 


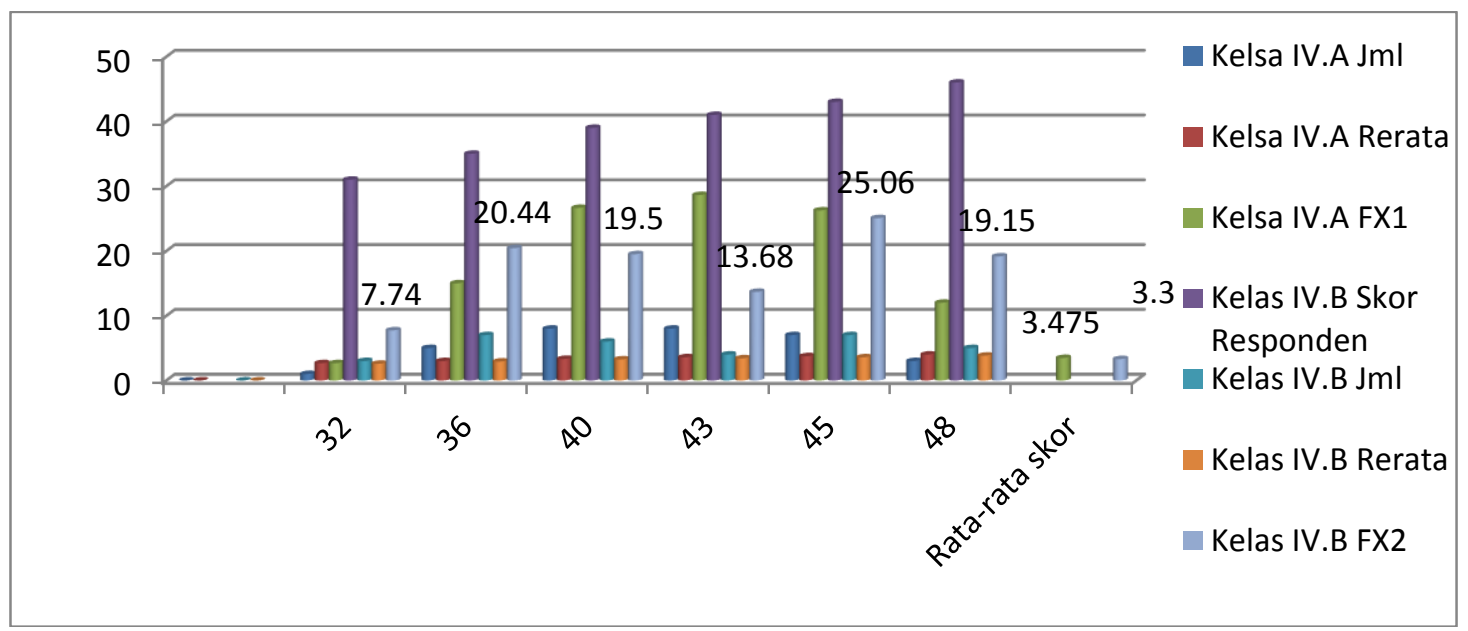

Figure 3. Diagram of mean in respondents' answers

From the diagram in figure 3 appears that the average of respondents' answers to the student worksheet teaching material product using the inductive thinking model in $4^{\text {th }} \mathrm{A}$ grade is 111.20 , with the average answer for all students 3,475 , which is in Green. If the results are consulted with table 9 which is about classification of perceptions based on the number of answers, then including "Very Good" ,. This is clearly also seen from the results obtained in class IV-B, for the total score of answers in class IV-B is 105.57 , while the average is 3.30 . which is colored Blue. If the results are consulted with a classification table based on the total score of the answers, then the result is "Very Good",

The data above supports the process of student learning activities using student worksheet teaching material products with inductive thinking models, where in the process of learning students seemed to think more creatively for learning and students understood learning materials more easily. This is supported by the comparative test of the two groups by researchers with the " $\mathrm{t}$ " test with the help of the SPSS 18 program, where a Sig of $<0.05(0.00$ $<0.05)$ and analysis results to $>$ tt $(11,375>2,042)$ was obtained. From the results of the " $t$ " test, $\mathrm{H}_{\mathrm{a}}$ is accepted and $\mathrm{H}_{0}$ is rejected so it can be concluded that there are differences in students' critical thinking between students who used student worksheet based on inductive thinking learning models with students who used conventional learning teaching materials in Public Elementery School 66 Kota Bengkulu. Thus the teaching materials of science learning worksheets using inductive thinking models were better than the worksheets used previously in school. As explained previously, worksheet is a student learning tool that contains various activities that will be actively carried out by students. These activities can be in the form of observations, experiments, and asking questions (BedimoRung, Gustat, Tompkins, Rice, \& Thomson, 2016; Gestsdóttir, van Boxtel, \& van Drie, 2018; Huijgen, van de Grift, van Boxtel, \& Holthuis, 2017; Smith, Jones, Gilbert, \& Wieman, 2013; Stearns, Morgan, Capraro, \& Capraro, 2012). Worksheets are teaching materials that are packaged in an integrated manner so as to enable students to learn the material independently.

The results of this study are also reinforced by Karli (2012) who stated that thinking activities could be carried out by teachers through the teaching and learning process by involving their thoughts through learning models. Learning models can develop thinking skill such as inductive thinking (Agustriana, 2019; Deeley, 2010; Hamilton, Ying, \& Leskovec, 2017; Imran \& Suryani, 2018; Khosi'in, 2019; MoyanoFuentes \& Sacristán-Díaz, 2012; Olivares \& Escorza, 2012). Through this learning model, students can be more critical in solving problems in daily life. This research is also supported by Putri, Ardana, \& Ganing, (2014) who stated that the Integrative-based inductive learning model is a strategy to help students develop higher and creative thinking skills through observation, comparing, finding patterns and generalizing. Thus the problems faced by students and teachers in the teaching and learning process of science subject in elementary schools can be solved effectively. 


\section{CONCLUSION}

Based on the assessment of material experts and teachers and students' perceptions, the teaching material based on science learning models based on inductive thinking models obtains good results and is applicable in use as learning material.

There is a significant difference between students who use science teaching materials based on inductive thinking models with conventional learning teaching materials at SDN 66 Bengkulu City in improving students' critical thinking using SPSS at sig $0.00<0.05$ and with manual scores "T" count $<$ "t 'table (11.375 $<2.042)$.

\section{REFERENCES}

Aditama, F. (2015). Efektivitas pembelajaran induktif berbantuan geogebra pada materi garis singgung persekutuan dua lingkaran di kelas VIII SMP Negeri 1 Surabaya. MATHEdunesa, 3(3).

Afat, N., \& Kadığlu Ateş, H. (2019). A Case Study Investigating the Language Development Process, Early Literacy Experiences and Educational Problems of a Gifted Child. Journal for the Education of Gifted Young Scientists, 6(4), 36-71. https://doi.org/10.17478/jegys.2018.83

Agustriana, N. (2019). PENGARUH METODE EDUTAINMENT DAN IDENTITAS DIRI TERHADAP KETERAMPILAN SOSIAL ANAK. Al-Fitrah, 1(2), 216-228. https://doi.org/http://dx.doi.org/10.293 00/alfitrah.v2i1.1517

Alannasir, W. (2016). PENGARUH PENGGUNAAN MEDIA ANIMASI DALAM PEMBELAJARAN IPS TERHADAP MOTIVASI BELAJAR SISWA KELAS IV SD NEGERI MANNURUKI. Journal of Educational Science and Technology (EST), 2(2), 81. https://doi.org/10.26858/est.v2i2.2561

Amin, A. (2017). PENGEMBANGAN BAHAN AJAR PAI ASPEK AKHLAQ BERBASIS PENDEKATAN
PEMBELAJARAN DEMOKRATIK DALAM MENINGKATKAN PEMAHAMAN KONSEP SISWA SMPN 12 KOTA BENGKULU. Manhaj: Jurnal Penelitian Dan Pengabdian Masyarakat, 2(3). https://doi.org/10.1161/.V5I3.755

Bathgate, M., \& Schunn, C. (2017). The psychological characteristics of experiences that influence science motivation and content knowledge. International Journal of Science Education, 39(17), 2402-2432. https://doi.org/10.1080/09500693.2017. 1386807

Bedimo-Rung, A. L., Gustat, J., Tompkins, B. J., Rice, J., \& Thomson, J. (2016). Development of a Direct Observation Instrument to Measure Environmental Characteristics of Parks for Physical Activity. Journal of Physical Activity and Health.

https://doi.org/10.1123/jpah.3.s1.s176

Bibigul, A., Orynkul, S., Lyudmila, K., \& Aelita, S. (2015). The Rating System of the Rural School Pupils' Assessment of the Republic of Kazakhstan. Procedia - Social and Behavioral Sciences, 186, 1152-1158. https://doi.org/10.1016/j.sbspro.2015.04 .127

Borg, W. R., \& Gall, M. D. (1983). Education Researcb: An Introducation. New York \& London: Longman Inc.

Buckingham, D., \& Scanlon, M. (2001). Parental pedagogies: An analysis of british 'edutainment $\Leftrightarrow$ magazines for young children. Journal of Early Childhood Literacy, 1(3), 281-299. https://doi.org/10.1177/1468798401001 3003

Carlson, R. P. (1982). The Student Teaching Experience: A Means and a Medium. Journal of Physical Education, Recreation \& Dance, 53(6), 60-62. 
https://doi.org/10.1080/07303084.1982. 10629434

Deeley, S. J. (2010). Service-learning: Thinking outside the box. Active Learning in Higher Education. https://doi.org/10.1177/1469787409355 870

Freestone, M., \& O’Toole, J. M. (2016). The impact of childhood reading on the development of environmental values. Environmental Education Research, 22(4), 504-517.

https://doi.org/10.1080/13504622.2014. 989962

Gestsdóttir, S. M., van Boxtel, C., \& van Drie, J. (2018). Teaching historical thinking and reasoning: Construction of an observation instrument. British Educational Research Journal.

https://doi.org/10.1002/berj.3471

Hamilton, W. L., Ying, R., \& Leskovec, J. (2017). Inductive representation learning on large graphs. Advances in Neural Information Processing Systems.

Huijgen, T., van de Grift, W., van Boxtel, C., \& Holthuis, P. (2017). Teaching historical contextualization: the construction of a reliable observation instrument. European Journal of Psychology of Education. https://doi.org/10.1007/s10212-0160295-8

Imran, R. F., \& Suryani, N. A. (2018). Preoperational Development of Eearly Childhood with Insectarium Media. Jurnal Obsesi: Jumal Pendidikan Anak Usia Dini, 2(2), 267-271.

Karli, H. (2012). Model Pembelajaran untuk Mengembangkan Keterampilan Berpikir. Jurnal Pendidikan Penabur, 18(11), 56-66.
Khosi'in, K. (2019). Pengembangan Bahan Ajar Ilmu Lingkungan Pada Materi Konversi Sampah Plastik Menjadi Bahan Bakar Minyak, Sebagai Implementasi QS. ArRum Ayat 41 di Prodi IPA Fakultas Tarbiyah Dan Tadris IAIN Bengkulu. IJIS Edu: Indonesian Journal Of Integrated Science Education, 1(1), 90-99. https://doi.org/10.29300/ijisedu.v1i1.17 39

Kristyowati, R., \& Purwanto, A. (2019). Pembelajaran Literasi Sains Melalui Pemanfaatan Lingkungan. Scholaria: Jurnal Pendidikan Dan Kebudayaan, 9(2), 183-191. https://doi.org/10.24246/j.js.2019.v9.i2. p183-191

Moyano-Fuentes, J., \& Sacristán-Díaz, M. (2012). Learning on lean: A review of thinking and research. International Journal of Operations and Production Management. https://doi.org/10.1108/0144357121122 6498

Olivares, S. L. O., \& Escorza, Y. H. (2012). Desarrollo del pensamiento crítico en ambientes de aprendizaje basado en problemas en estudiantes de educación superior. Revista Mexicana de Investigacion Educativa.

Ondeng, S. (2007). MORALITAS ANAK DAN KAITANNYA DENGAN URGENSI PENDIDIKAN ISLAM. Lentera Pendidikan: Jurnal Ilmu Tarbiyah Dan Keguruan, 10(1), 107-115. https://doi.org/10.24252/lp.2007v10n1a 8

Prasetyaningtyas, F. D. (2019). Inovasi Model Quantum Learning Menggunakan Teori Apersepsi Berbasis Karakter untuk Meningkatkan Kualitas Pembelajaran Matakuliah Pendidikan IPS SD. ELSE (Elementary School Education Journal): Jurnal Pendidikan Dan Pembelajaran Sekolah Dasar, 3(2).

https://doi.org/10.30651/else.v3i2.2682 
Prastowo, A. (2013). Panduan Kreatif Membuat Bahan Ajar Inovatif. Yogyakarta: DIVA Press.

Prince, M., \& Felder, R. (2007). The many faces of inductive teaching and learning. Journal of College Science Teaching, 36(5), 14.

Prince, M. J., \& Felder, R. M. (2006). Inductive teaching and learning methods: Definitions, comparisons, and research bases. Journal of Engineering Education, 95(2), 123-138.

Putri, I. A. A. L., Ardana, I. K., \& Ganing, N. N. (2014). PENGARUH MODEL PEMBELAJARAN INDUKTIF BERBASIS INTEGRATIF TERHADAP HASIL BELAJAR IPA SISWA KELAS V SEMESTER I SEKOLAH DASAR GUGUS R.A KARTINI. MIMBAR PGSD Undiksha, 2(1). https://doi.org/10.23887/JJPGSD.V2I1. 2273

Raharjo, S. B. (2012). Evaluasi trend kualitas pendidikan di indonesia. Jurnal Penelitian Dan Evaluasi Pendidikan, 16(2), 511-532.

Riswanto, R., \& Dewi, N. A. K. (2017). Peningkatan Keterampilan Proses Sains Melalui Pembelajaran Berbasis Laboratorium Untuk Mewujudkan pembelajaran Berkarakter. Jurnal Riset Dan Kajian Pendidikan Fisika, 4(2), 60. https://doi.org/10.12928/jrkpf.v4i2.8164

Rudyanto, H. E. (2016). MODEL DISCOVERY LEARNING

DENGAN PENDEKATAN SAINTIFIK BERMUATAN KARAKTER UNTUK MENINGKATKAN KEMAMPUAN BERPIKIR KREATIF. Premiere Educandum: Jurnal Pendidikan Dasar Dan Pembelajaran, $\quad 4(01)$. https://doi.org/10.25273/pe.v4i01.305
Rusnilawati, R. (2016). Pengembangan perangkat pembelajaran matematika bercirikan active knowledge sharing dengan pendekatan saintifik kelas VIII. Jurnal Riset Pendidikan Matematika, $\quad 3(2), \quad 245$. https://doi.org/10.21831/jrpm.v3i2.1063 3

SAREGAR, A., IRWANDANI, I., ABDURRAHMAN, A., PARMIN, P., SEPTIANA, S., DIANA, R., \& SAGALA, R. (2019). Temperature and Heat Learning Through SSCS Model with Scaffolding: Impact on Students Critical Thinking Ability. Journal for the Education of Gifted Young Scientists, 6(3), 39-54. https://doi.org/10.17478/jegys.2018.80

Selviani, I. (2019). Pengembangan Modul Biologi Problem Based Learning Untuk Meningkatkan Kemampuan Berpikir Kritis Peserta Didik SMA. IJIS Edu: Indonesian Journal of Integrated Science Education, $1(2)$. https://doi.org/10.29300/ijisedu.v1i2.20 32

Smith, M. K., Jones, F. H. M., Gilbert, S. L., \& Wieman, C. E. (2013). The classroom observation protocol for undergraduate stem (COPUS): A new instrument to characterize university STEM classroom practices. CBE Life Sciences Education. https://doi.org/10.1187/cbe.13-08-0154

Stearns, L., Morgan, J., Capraro, M., \& Capraro, R. (2012). A Teacher Observation Instrument for PBL Classroom Instruction. Journal of STEM Education: Innovations and Research.

Styawati, P. S., \& Rizal, S. (2017). Teaching Reading Comprehension Through Snowball Throwing Teaching Technique. At-Ta'lim : Media Informasi Pendidikan Islam, 13(2), 275-300.

Sugiyono. (2007). Metode Penelitian Kualitatif, Kuantitatif dan R\&D. Bandung: Alfabeta. 
Sulistyowati, Y., \& Sugiman, S. (2014).

Pengembangan Perangkat Pembelajaran Bangun Ruang di SMP dengan Pendekatan Creative Problem Solving. Pythagoras: Jurnal Pendidikan Matematika, 9(2), 219-232. https://doi.org/10.21831/pg.v9i2.9082

Sutarto, S., Indrawati, I., Prihatin, J., \& Dwi, P. A. (2018). Geometrical Optics Process Image-Based Worksheets for Enhancing Students' Higher-Order Thinking Skills and Self-Regulated Learning. Jurnal Pendidikan IPA Indonesia, 7(4), 376-382. https://doi.org/10.15294/jpii.v7i4.14563 